Paper Number: 2003-2320

\title{
Study Abroad: Impact on Engineering Careers
}

\author{
Susannah R. Spodek \\ Senior Program Officer \\ Global Engineering \\ Education Exchange, \\ Institute of \\ International Education \\ New York, NY
}

\author{
Lester Gerhardt \\ Professor, Electrical, \\ Computer and Systems \\ Engineering \\ Professor,Computer Science \\ Associate Dean, School of \\ Engineering \\ Rensselaer Polytechnic \\ Institute \\ Troy, NY
}

\author{
D. Joseph Mook \\ Prof. Mechanical and Aerospace \\ Engineering \\ Asst. Dean, School of \\ Engineering and App. Science \\ University at Buffalo, State \\ University of NY \\ Buffalo, NY
}

"As an engineer I didn't think it was possible to study abroad. But my friend studied in Denmark, and he said anybody can study abroad, so I did a lot of research and found I could take classes for credit overseas. The only reason I might not have gone abroad is because it was my last year and I was worried about missing on-campus recruitment... But, out of 35 industrial engineers who graduated, only 10 had job offers, and I was the only one with two offers! Study abroad definitely gives you an edge!"

--Megan Gibbs, graduate of the University of Wisconsin-Madison, 2002, studied in Denmark in the fall 2001 semester through the Global Engineering Education Exchange program. Megan received a scholarship from $\mathrm{ABB}$ that assists female engineering students to study abroad. She was the only person that ABB hired at UW-M in 2002.

\begin{abstract}
In this paper we establish that study abroad, as part of an engineering education, can significantly improve the set of skills new engineers bring to their fields, in the process improving their career opportunities and better meeting the demands of the job market. Data in this paper come from on-going research being conducted by the Institute of International Education for the National Science Foundation with alumni of the Global Engineering Education Exchange (Global E ${ }^{3}$ ) program, as well as on-line research of the hiring practices and articulated needs of industry and anecdotal evidence from faculty and Global $E^{3}$ alumni.
\end{abstract}

I. Traditional engineering education is not meeting marketplace needs 
In recent years, even as engineering fields face shortages in the labor supply, there have been calls from industry for those newly entering the workforce to come better prepared. Graduating engineering students, in addition to their technical educations, are expected to be prepared with "soft skills," work experience, and a wide-ranging background not typically provided for in a traditional engineering program. According to Brenda Cox, Manager for International and Advanced Procurement, BMW Manufacturing Corporation, "you must not only be skilled in your area of expertise, but be flexible and have what is often called the 'soft skills'. These soft skills are needed to maximize your effectiveness within an organization." ABET (the Accreditation Board for Engineering and Technology), recognizing the changes in the field, incorporated them into the EC 2000 guidelines, requiring that engineering education programs provide "the broad education necessary to understand the impact of engineering solutions in a global and societal context," including "hard" and "soft" skills.

In March 2001, CENews published the transcript of a roundtable discussion among engineers on the results of surveys conducted by CENews and Roger Williams University entitled, "What Employers Want From New Hires - and What They're Getting." During the discussion that focused on the disconnect between industry wants and new hires' expectations, they delved into the subject of engineering education. Roundtable host, Igor Runge, Dean of Roger Williams University's School of Engineering, summarized, "[W]e've talked about [what] we need to incorporate perhaps more in the education, so that students [who graduate are] more prepared for a job, and that includes management skills, written skills, oral communication skills, ethics, technical skills, more broad-based knowledge, more emphasis on humanities, and it goes on. What can we do as an institution, as a university, as a program? Where can we cut to incorporate more of the positive needs? Is there anything we're... too good at? How can we get more things into the 'box' without increasing the box?" [Italics added for emphasis.] There followed a discussion of ways to incorporate required, zero-credit seminars, and other methods for increasing the amount squeezed into the four-year degree, as well as the possibility that the length of degree programs may need to be extended.

\section{Study abroad helps to meet market place needs}

A semester or a year of study abroad (complemented, if so desired, with an internship abroad), can provide students with many of the skills that traditional engineering programs have trouble providing. Based on our research, students routinely return from study abroad feeling more confident, better able to express themselves, better able to communicate, more flexible and independent, more willing and able to view issues from multiple perspectives, with a better understanding of the world, and in summation, better able to think outside of the box. According to Katherine Boettrich, vice president, Communications and Sustainability Affairs for ABB Inc., "Early opportunities to study and learn in the global community help students become innovators and critical thinkers. It helps them better prepare to become international leaders of tomorrow."33

Surprisingly, even with the push from senior and middle management in industry, and new 
ABET criteria emphasizing precisely the skills provided through study abroad, many faculty remain unconvinced of the importance of international education. Perhaps even more surprising, recruiters of new graduates rarely emphasize international education in their recruiting tactics.

For example, the Global $\mathrm{E}^{3}$ program has occasionally encountered faculty members who dismiss the quality of courses their US students take abroad (although this is not as much of a problem for in-coming international students who have taken the same courses abroad). Recruiters very rarely indicate study abroad as a desired (let alone) required criterion for employment. The following quote from a human resources director, from ongoing joint research being conducted by the Institute of International Education, the British Council, the German Academic Exchange Service, and the Australian Education Office, reflects this sentiment, "Overall, we'd need to be convinced of the merits of international education and how it helps the student meet our criteria and our business needs. Right now, other than demonstrating individual initiative and a global awareness, a degree or semester or year study in Australia, Germany or the UK is not seen as an advantage or positive distinction as it doesn't directly impact our business needs here in the US." 4

Recognizing the limited study abroad opportunities available to engineers until the 1990s, the Global $E^{3}$ consortium was formed in 1994 by a group of faculty of American and Western European engineering institutions in order to offer study abroad exchange opportunities to their students. The consortium was quickly expanded to other world areas, including Latin America, Eastern Europe, East and Southeast Asia, and the Middle East. There are now 33 member institutions in the United States, and students at these schools may study in any of the more than 70 partner institutions in 17 countries. Many of these overseas institutions offer engineering courses in English, even in countries where the local language is not English, such as in Denmark, Hungary, Turkey, and Japan, as well as English engineering courses in locations where English is widely used, such as in the UK, Singapore, and Hong Kong. Students at any member US institution can study abroad at any overseas partner institutions, and students at overseas partner institutions can study at US member institutions. Global $\mathrm{E}^{3}$ is centrally administered in the United States by the Institute of International Education (IIE), the oldest and largest American organization specializing in international education. ${ }^{5}$

\section{Research Demonstrates That Study Abroad Meets Industry Needs}

IIE is currently conducting research to look at the impact of study abroad on careers. Roughly 350 recent graduates from US member engineering institutions have studied abroad through Global $\mathrm{E}^{3}$. Some went on to graduate school, but most went straight to work (a few did both). The following preliminary results are based on roughly 40 responses. Of the respondents, 14 (34\%) were mechanical engineering majors; 7 (17\%) electrical engineering; $6(15 \%)$ industrial engineering majors; $5(12 \%)$ aerospace engineering majors; $5(12 \%)$ chemical engineering; and the balance were materials engineering, civil engineering, and other majors. 
These preliminary responses support the following conclusions: ${ }^{6}$

1) Study abroad provides an education in many of the "soft skills" required by ABET and industry. In our research, $70 \%$ or more of respondents "strongly agree" or "agree" with statements such as:

- "My Global E $\mathrm{E}^{3}$ experience helped make me more independent and selfsufficient."

- "My Global E $\mathrm{E}^{3}$ experience helped to strengthen my interpersonal skills."

- "I gained an understanding of professional practices \& standards in other countries."

- "My participation in the Global $E^{3}$ program helped me to develop the ability to function in a multi-cultural work setting."

- "My participation in the Global $E^{3}$ program helped me to develop the ability to function on multi-disciplinary teams."

- "My participation in the Global $\mathrm{E}^{3}$ program helped me to develop the ability to communicate effectively."

2) Over $60 \%$ of respondents learned technical skills overseas, often from a perspective not taught in the US (see discussion below).

3) However, few recruiters actively seek applicants with study abroad experience, and do not see value in that experience. They do not seem to recognize the connections between study abroad experience and many of the skills that they are seeking in new recruits. As one respondent put it bluntly, "It seems that HR people don't care about international experience."

4) Although, study abroad does not necessarily help a student get an interview, once the student meets with the potential employer, the experiences of the study abroad experience and the skills gained during that time become more obvious to the interviewer, and help to set the applicant apart from other applicants, giving him/her an edge. In a comment that reflected many responses, one respondent noted, "my experiences through Global $\mathrm{E}^{3}$ have given me many answers to questions in interviews." Another respondent noted that study abroad "helped in looking for a job. Although most employers were not directly looking for someone with international experience, they were all amazed at someone being able to study engineering in a foreign language. So it was valuable as a mark of excellence to distinguish me from other students."

5) Once hired, there is anecdotal evidence that since those students with study abroad experience are better skilled, they obtain a faster track for positions of leadership and management. One respondent wrote, "I had made the comment earlier that I feel that HR (and recruiters) don't care about international experience. However, I have found that when I talked to upper management and told them of my international background, they were really interested and fascinated."

\section{Skills Engineers Develop Through Study Abroad}

Survey respondents and interviewees have indicated that their study abroad experiences were important in helping them to develop the following "soft" skills: 
- Flexibility -through their experiences in new places in unfamiliar cultures, they learned to adapt, think creatively to develop new solutions, and to be flexible.

- Appreciation for diversity - alumni reported that during their time overseas they learned to recognize and appreciate the differences, as well as the similarities, in cultures and in people.

- Open-mindedness- alumni noted that experiencing life as a foreigner helped them to be more open, patient, tolerant and understanding of others.

- Comfortable with "international" - having spent time abroad and meeting people from around the world, alumni were much more comfortable working on international teams, attending international meetings, and communicating with people in other countries.

- Global perspective of engineering - alumni recognize that people all over the world work in this field and this perspective helped to give them a bond with other engineers. As one alumni put it, "When you come to work as an engineer, you hold the knowledge that on the other side of the world engineers are doing the same thing you are."

These skills are precisely the "soft" skills in which recruiters are interested. One program graduate conveyed the following, "My study abroad experience in general was the best thing that I did in my five years of schooling. I do not believe that I am 'better' than my classmate who perhaps had a co-op, I believe I bring my employer a more well-rounded perspective on business and cultural practices."

It is clear that study abroad offers excellent training in "soft" skills, but we were unsure how engineers evaluated the strength of the "hard" or technical skills they studied abroad. We were pleasantly surprised to find that over $60 \%$ of respondents answered yes to the following question, "Did your participation in the Global $\mathrm{E}^{3}$ program help you develop any pertinent technical skills? For example: experimentation, problem-solving, design, practical skills, etc." Among the "yes" responses, a number of respondents noted that they were able to conduct research not available at home, such as in low-energy building design.

V. Study abroad is a viable option for engineers

For many years, study abroad was seen as the domain of students in the liberal arts, a perk for language, history, and political science majors. ${ }^{7}$ Engineers, with their strictly defined curricula, felt there was little room for flexibility to allow them the opportunity to study abroad, especially within the 4-year degree. For the rare engineering student who investigated the possibility of studying abroad, $s$ /he faced multiple hurdles, from finding overseas academic programs (in English or in another language) that would meet his/her academic requirements to finding faculty who would approve the credit transfer.

Fortunately times have changed. Global $\mathrm{E}^{3}$, the largest consortium in engineering for study abroad, offers students engineering exchange opportunities in English and in other languages in 17 countries. Many schools of engineering in the United States now offer at least one or more opportunities for study abroad, and the types of opportunities for international engineering exchange are growing constantly. Some new areas for 
international exchange are overseas internships and co-ops, service learning projects, and academic short-term training programs. Each of these offers engineering students a different avenue to develop new skills and learning opportunities that complement traditional four-year programs.

\section{Conclusion}

The benefits of study abroad to engineers are obvious. At a time when many engineering educators are trying to meet the demands of industry and the new requirements of ABET, we suggest that schools of engineering consider study abroad as a tested and reliable path to meeting these goals. Further, we call on the heads of industry to publicize and encourage international experiences as a criterion for new hires. To quote one of the respondents, "It [study abroad] enhanced my education. It made studying more interesting. Instead of four similar years at one school, I got a major change for one year... It helped in looking for a job."

\section{Biographies}

Susannah Spodek, Senior Program Coordinator at the Institute of International Education, specializes in East Asian educational and training programs. She has administered the Global Engineering Education Exchange (Global $\mathrm{E}^{3}$ ) since 1998. She has studied and worked in international education in Asia and the Middle East. She earned a B.A. at Brandeis University in History, an M.A. in International Affairs at Columbia University, and an M.A. in International Education from Teachers College.

LESTER A. GERHARDT is Associate Dean of Engineering and Professor of Electrical, Computer and Systems Engineering as well as Professor of Computer Science, and Information Technology at Rensselaer Polytechnic Institute. He joined Rensselaer in 1970 after a decade in industry. He chaired the ECSE Department for 12 years, as well as serving as the Founding Director of the Manufacturing Center, the second such Center established in the US. He has a PhD from State University of New York at Buffalo in Electrical Engineering, and was awarded an honorary Doctorate by the Technical University of Denmark in 2000. He is a Fellow of ASEE as well as the IEEE among other honors and awards. In addition to his administrative responsibilities, he regularly teaches Discrete Time Systems, and Voice and Image Processing courses. His areas of research include digital signal processing emphasizing voice and image processing, personnel verification using biometrics, automated inspection, and technology aids for the disabled. He is the Chair of the Executive Board of the Global E ${ }^{3}$ Program. In 2002, Lester Gerhardt was named the inaugural recipient of the newly established ASEE Engineering Research Council Research Administration Award.

D. JOSEPH (JOE) MOOK is Professor of Mechanical and Aerospace Engineering, and Assistant Dean for International Education, in the School of Engineering and Applied Sciences at the University at Buffalo, State University of New York. He is a member and Chair-Elect of the Executive Committee of the Global Engineering Education Exchange, and a member of the UB Council of International Scholars and Programs. Dr. Mook received a B.S. degree in Engineering Science and Mechanics from Virginia Polytechnic Institute and State University (Virginia Tech) in 1979. He then worked as an Analytical Engineer at Pratt and Whitney Aircraft in East Hartford, Connecticut, before returning to graduate study in 1981. He earned an M.S. in 1982 and a Ph.D. in 1985, both in Engineering Mechanics from Virginia Tech, and joined the faculty at UB in 1986. Dr. Mook's areas of research include nonlinear system identification and controls, spacecraft dynamics, and automated flight dynamics and controls, and he 
teaches courses in these areas and related topics.

${ }^{1}$ Cox, Brenda. "The Effective Engineer: Development of the 'Soft Skills."” Presentation at the University of Rhode Island, Fifth International Colloquium on International En gineering Education. October 24, 2002 (http://www.uri.edu/iep/colloquia/2002/effective_engineer.pdf)

${ }^{2}$ Murphy, Cathy and Shanon Fauerbach, "The CENews Roundtable: What employers want from new hires - and what they're getting," CENews. March 2001.

(http://department.rwu.edu/ engineering/cenewsfeature.htm)

${ }^{3}$ Boettrich, Katherine. "ABB and Global $\mathrm{E}^{3}$ award scholarships to three women for engineering study abroad." Press release, February 14, 2003.

${ }^{4}$ J. Walter Thompson Communications. "Status Report for the Market Research Proposal To Better Understand the Market for Overseas Education in the US." March 3, 2003. Findings will be included in report to FIPSE (Fund for the Improvement of Post-Secondary Education) by September 1, 2003.

${ }^{5}$ Gerhardt, Lester, Peggy Blumenthal, and Susannah Spodek. "Educating the Global Engineer: A

Program to Promote Study Abroad, International Exchanges and Diversity in Undergraduate

Engineering."

2002 American Society for Engineering Education.

${ }^{6}$ Research is being conducted with a grant from the National Science Foundation (NSF). A final report will be submitted to NSF by September 1, 2003 and will be posted at: www.iie.org/pgms/global-e3.

${ }^{7}$ For more information about the majors of study abroad students, and related information, see the following annual publication: Koh Chin, Hey-Kyung, ed. Open Doors: Report on International Educational Exchange. Institute of International Education. 